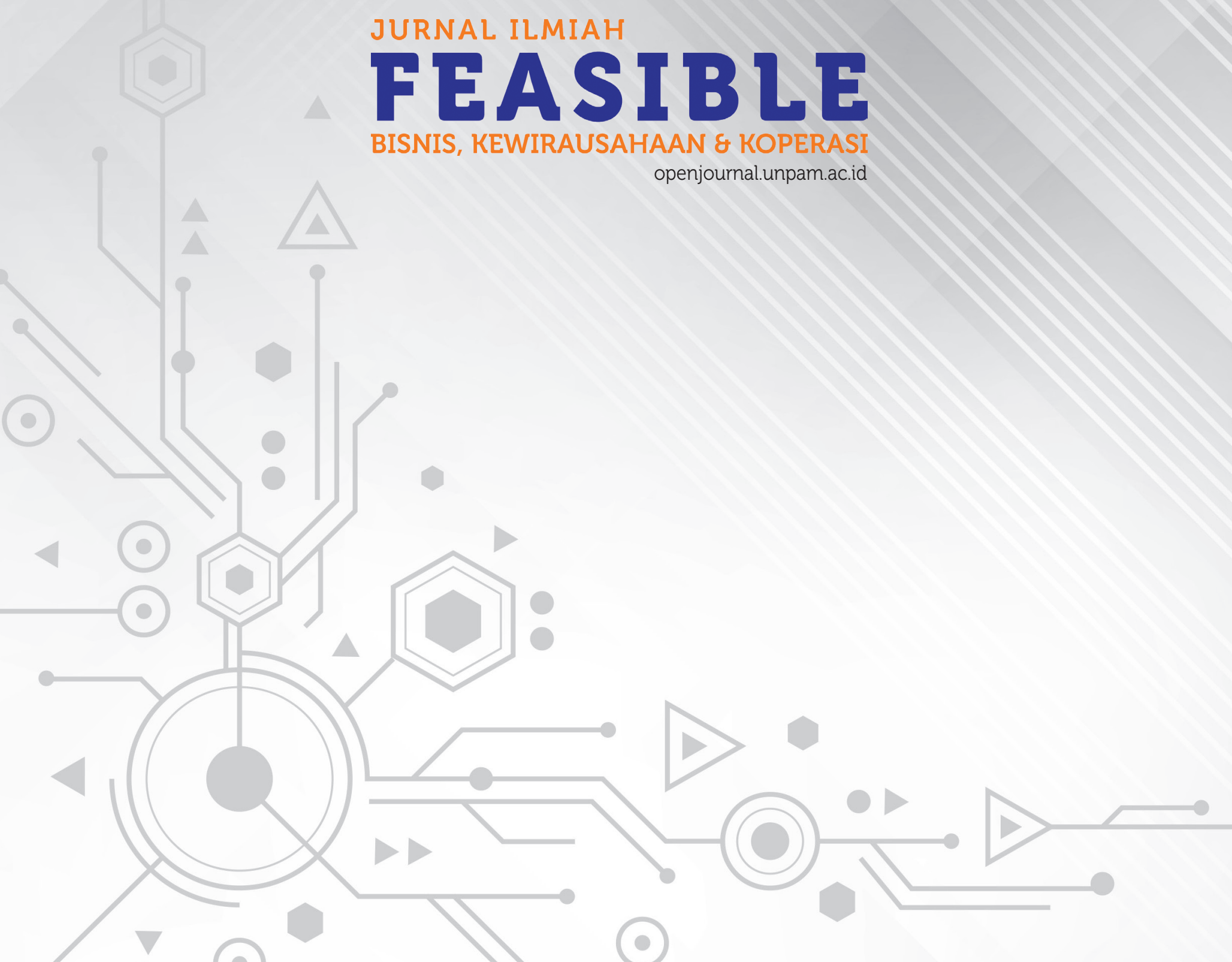




\title{
ANALISIS STRATEGI PENGEMBANGAN PEMASARAN PRODUK SANGDO AGRICULTURE
}

\author{
Umi Rusilowati \& Fitrah Jaya Atmaja
}

\begin{abstract}
Abstrak
Tujuan dari penelitian ini adalah untuk mengetahui dan menganalisis secara deskriptif Strategi Pengembangan Pemasaran Produk Sangdo Agriculture pada PT.Altrak 1978 serta strategi-strategi untuk mengatasi kendala dalam implementasinya. Penelitian ini menggunakan pendekatan kualitatif dengan single case study. Hasil penelitian menunjukkan bahwa berdasarkan analisis posisi pada matriks SWOT, dapat diketahui bahwa PT. Altrak 1978 berada pada posisi kuadran 1, posisi perusahaan pada kuadran ini mendukung strategi agresif, perusahaan memiliki peluang dan kekuatan sehingga perusahaan dapat memanfaatkan peluang tersebut, strategi yang harus diterapakan pada kondisi ini adalah mendukung kebijakan pertumbuhan yang agresif, rekomendasi strategiyang sesuai adalah perluasan dan memaksimalkan kekuatan internal perusahaan.PT.Altrak 1978 dapat melakukan strategi seperti pengembangan pasar, inovasi produk dan pengembangan produk.
\end{abstract}

Kata Kunci: Strategi Pengembangan Pemasaran, Analisis SWOT, Analisis SPACE.

\begin{abstract}
The purpose of this study is to investigate and analyze descriptively Sangdo Agriculture Product Marketing Development Strategy at PT.Altrak 1978 as well as strategies to overcome obstacles in its implementation. This research uses qualitative approach with single case study. The result shows that based on position analysis on SWOT matrix, it can be seen that PT.Altrak 1978 is in quadrant 1 position, position in this quadrant supports aggressive strategy, company has opportunity and strength so company can take advantage of the opportunity, this condition is to support an aggressive growth policy, the appropriate strategy recommendation is to expand and maximize the company's internal strength. PT.Altrak 1978 can perform strategies such as market development, product innovation and product development.
\end{abstract}

Keywords: Marketing Development Strategy, SWOT Analysis, SPACE Analysis.

\section{PENDAHULUAN \\ Latar Belakang Masalah}

Tinggi-nya kebutuhan akan peralatan pertanian dan konstruksi di Indonesia merupakan pasar yang menarik bagi pabrikan alat berat dan peralatan pertanian negara lain. Perubahan sosial ekonomi yang terus terjadi dalam proses perkembangan suatu negara membuahkan tantangan baru dalam dunia bisnis. Para pengembang pemasaran harus dapat mengembangkan konsep pemasaran yang berorientasi pada konsumen. Perusahaan harus dapat memenuhi tuntutan konsumen tentang pelayanan yang lebih baik dan memuaskan serta dapat menyediakan barang atau jasa yang sesuai dengan kebutuhan dan keinginan para konsumen.

Semakin banyaknya tersedia pilihan produk membuat konsumen lebih cenderung menjatuhkan pilihan sesuai dengan persepsi mereka terhadap merek-merek tertentu yang diyakini konsumen dapat memenuhi ekspektasi mereka termasuk kualitas produk, inovasi produk serta brand image produk. Perusahaan-perusahaan 
berlomba-lomba memperluas pangsa pasarnya, mencoba menarik para pelanggan dengan cara mempengaruhi sikap konsumen agar bersedia membeli produk-produk mereka.

Perkembangan ekonomi yang terjadi juga mempengaruhi perkembangan dibidang teknologi, hal ini yang menyebabkan perusahaan dituntut untuk lebih kreatif dan inovatif dalam menghadapi persaingan di dunia bisnis, dan dengan semakin ketatnya persaingan maka dibutuhkan strategi pemasaran yang tepat untuk mencapai tujuan perusahaan, karena strategi pemasaran merupakan senjata terpenting dalam mempertahankan dan mengembangkan eksistensi kelangsungan hidup dari sebuah perusahaan. Perusahaan yang berhasil adalah perusahaan yang pandai dalam menyiasati perkembangan bisnis yang terjadi serta dapat menangkap setiap peluang-peluang yang ada untuk memenangkan sebuah persaingan, tentunya dengan strategi dan cara yang efektif dan efisien antara lain dengan penyediaan produk dengan tehnologi terbaru, inovatif, menyiapkan pelayanan purna jual atau after sales service dan menjaga brand image product, dimana hal ini bertujuan untuk memberikan kepuasan kepada pelanggan (customer satisfaction) yang pada akhirnya akan meningkatkan kepercayaan pelanggan terhadap produk yang di jual, selanjutnya akan meningkatkan volume penjualan perusahaan. Setiap pembelian peralatan konstruksi dan alat berat biasanya di ikuti dengan pelayanan purna jual yang di dikenal juga dengan nama After Sales Service yaitu suatu bentuk pelayanan yang di lakukan oleh distributor alat berat setelah transaksi penjualan terjadi sebagai suatu bentuk tanggung jawab distributor terhadap produk yang di jual, pelayanan tesebut tidak hanya terpaku di kantor-kantor distributor alat berat di kota-kota, tapi juga meliputi pelayanan mobile atau sampai kepada dimana lokasi peralatan berat tersebut berada, tidak jarang distributor alat berat mendirikan kantor cabang atau depo di pelosok-pelosok pedalaman demi untuk menjangkau pelayanan terhadap customer yang membeli peralatan tersebut.

Semakin baik pelayanan purna jual dilakukan perusahaan kepada pelanggan maka akan semakin mudah pelanggan dalam mengingatnya sehingga posisioning perusahaan tersebut di benak pelanggan semakin kuat. Oleh karena itu banyak sekali perusahan alat berat yang berani mengeluarkan anggaran yang tidak sedikit untuk kegiatan promosi dan pelayanan purna jual. Beberapa perusahaan penyedia peralatan berat dan konstruksi yang menyediakan pelayanan purna jual antara lain PT.United
Tractors. Tbk. Perusahaan ini salah satu group Astra yang merupakan distributor tunggal dari mesin-mesin dan heavy equipment buatan Jepang dengan merek Komatsu, selanjutnya PT. Trakindo Utama adalah salah satu perusahaan nasional yang dimiliki pengusaha Indonesia yang mendistribusikan mesin-mesin dan alat-alat berat buatan Amerika dengan merek Caterpillar, kemudian adalah PT. Hexindo Adiperkasa Tbk. Perusahaan ini adalah distributor tunggal atas mesin-mesin dan alat-alat berat asal Jepang dengan merek Hitachi, PT Intraco Penta agen alat berat merek Volvo dan Ingersollrand, PT. United Equipment agen peralatan berat merek Terex.

PT. ALTRAK 1978 adalah salah satu perusahaan alat-alat berat dari group perusahaan Cipta Cakra Murdaya yang mendistribusikan mesin-mesin dan peralatan dari berbagai negara Eropa, Amerika, Inggris, dan Jepang, merek-merek yang diageni PT.Altrak 1978 antara lain Cummins mesin pembangkit listrik dari negara asal USA, JCB peralatan konstruksi dari negara asal Inggris, Locateli Crane dari negara Italia, Kawasaki Wheel Loader dari negara Jepang dan New Holland tractor pertanian dari Italia, Sangdo Attachement serta beberapa produk lainnya yang melengkapi line product PT.Altrak 1978.

Product Sangdo adalah salah satu produk peralatan pendukung perusahaan konstruksi dan pertanian yang di distribusikan oleh PT.Altrak 1978 dengan merek dagang Sangdo International. Produk asal Korea ini mulai di ageni oleh PT.Altrak 1978 sejak tahun 2014 sampai dengan saat ini. Produk Sangdo digunakan di sektor konstruksi, pertambangan dan pertanian sebagai equipment penunjang dari equipment utama. Breaker atau alat pemecah batu atau concrete beton yang di produksi Sangdo adalah salah satu produk attachment untuk Excavator yang di pasarkan PT.Altrak 1978 pada segmen pertambangan dan konstruksi, produk selanjutnya adalah Sangdo Graber Crane atau alat bantu panen buah sawit pada segmen agriculture, produk ini merupakan alat mekanisasi pertanian yang sangat membantu para pengusaha di perkebunan sawit dalam meningkatkan efisiensi dan efektifitas biaya panen, produk ketiga adalah Sangdo Truck Mounted Crane yaitu alat angkut berupa Crane yang di install pada Truck Head, produk ini di pasarkan pada segmen konstruksi, oil \& gas, transportasi serta mining .

Untuk mengatasi rendahnya tingkat kepuasan pelanggan dan untuk meningkatkan penjualan maka idealnya dilakukan upaya untuk menerapkan strategi pengembangan pe- 
masaran dan peningkatan kualitas pelayanan purna jual pada produk Sangdo mengingat persaingan di antara kompetitor yang sangat ketat, pelayanan purna jual termasuk garansi dan ketersedian suku cadang merupakan hal yang sangat penting bagi pelanggan sebelum memutuskan untuk membeli produk. PT.Altrak juga perlu melihat lebih dalam untuk memenuhi kebutuhan pelanggannya termasuk inovasi produk mengingat pemasaran produk yang banyak di temui di pasaran apalagi dengan market penetration yang sudah lebih dulu dilakukan competitor.

Berdasarkan uraian di atas maka dilakukan penelitian pada PT.Altrak 1978 dengan judul : "Analisis Strategi Pengembangan Pemasaran Produk Sangdo Agriculture studi kasus di PT. Altrak 1978 "

Pentingnya judul ini diteliti melihat kondisi dan tantangan yang di hadapi PT.Altrak 1978 di lapangan dalam menghadapi para pesaingnya serta banyaknya keluhan dari pelanggan terhadap produk ini serta rendahnya tingkat penjualan produk ini di PT.Altrak 1978.

\section{Fokus Penelitian}

1. Penelitian ini menganalisa daya saing produk Sangdo Agriculture di PT.Altrak 1978

2. Penelitian strategi bersaing pemasaran ini di lakukan khusus pada produk Sangdo Agriculture yang merupakan penelitian single case atau single unit analysis.

3. Penelitian ini mengkaji dan menganalisa guna menetapkan strategi pemasaran yang lebih tepat bagi produk Sangdo Agriculture PT.Altrak 1978.

\section{Rumusan Masalah}

1. Bagaimana strategi pemasaran product Sangdo Agriculture di PT.Altrak 1978 saat ini?

2. Bagaimana posisi daya saing produk Sangdo Agriculture di banding produk sejenis secara umum?

3. Bagaimana strategi yang lebih tepat bagi pemasaran produk Sangdo Agriculture di PT.Altrak 1978?

\section{Tujuan Penelitian}

1. Untuk mengetahui strategi pemasaran produk Sangdo Agiculture di PT.Altrak 1978 saat ini.

2. Untuk mengetahui posisi daya saing produk Sangdo Agriculture di PT.Altrak 1978 secara umum.

3. Untuk mengetahui bagaimana strategi yang lebih tepat bagi pemasaran produk Sangdo Agriculture di PT.Altrak 1978.

\section{Tinjauan Pustaka Manajemen}

Pengertian manajemen menurut R.Terry dalam buku asas manajemen, manajemen adalah suatu proses atau kerangka kerja yang melibatkan bimbingan atau pengarahan suatu kelompok orang orang ke arah tujuan organisasional atau maksud-maksud yang nyata. Usman Effendi (2014 : 3). Manajemen adalah suatu proses khas terdiri tindakan-tindakan perencanaan, pengorganisasian, penggerakan dan pengontrolan yang dilakukan dalam menentukan serta mencapai target yang sudah ditetapkan lewat pemanfaatan sumberdaya manusia dan lainnya.

Manajemen adalah suatu proses dalam membuat perencanaan, pengorganisasian, mengendalikan dan memimpin fungsi-fungsi itu berjalan terus menerus menggunakan segala sumber daya organisasi dalam mencapai sasaran, kegiatan utama di lakukan oleh seorang manajer Usman Effendy, (2014 :7).

\section{Pemasaran}

Pemasaran (marketing) menurut Kotler dan Armstrong, (2008:6) yaitu "sebagai proses dimana perusahaan menciptakan nilai bagi pelanggan dan membangun hubungan yang kuat dengan pelanggan dengan tujuan untuk menangkap nilai dari pelanggan sebagai imbalannya".

\section{Managemen Pemasaran}

Manajemen pemasaran menurut Djaslim Saladin (2003:3) adalah "Analisis, perencanaan, penerapan dan pengendalian program yang dirancang untuk menciptakan, membangun dan mempertahankan pertukaran yang menguntungkan dengan pasar sasaran dengan maksud untuk mencapai tujuan-tujuan organisasi”.

Strategi pemasaran adalah logika pemasaran dimana perusahaan berharap untuk menciptakan nilai pelanggan dan mencapai hubungan yang menguntungkan, Kotler \& Amstrong (2006).

\section{Pengembangan Pemasaran}

Pengembangan adalah suatu usaha untuk meningkatkan kemampuan teknis, teoritis, konseptual, dan moral untuk mencapai target perusahaan. Pengembangan pemasaran adalah suatu strategi dan rencana pemasaran yang mendalam dan kreatif yang dapat memandu kegiatan pemasaran. Pengembangan strategi pemasaran yang benar sepanjang waktu memerlukan bauran disiplin dan fleksibilitas. Perusahaan harus tetap berpegang pada strategi, tetapi juga menemukan cara baru untuk terus 
mengembangkannya. Pemasaran juga harus selalu meningkatkan strategi untuk sejumlah produk dan jasa di dalam organisasinya.

\section{Pengertian Pelayanan Purna Jual}

Philip Kotler (2002: 508) mengatakan "Layanan purna jual adalah layanan yang diberikan perusahaan kepada seorang konsumen setelah terjadinya transaksi penjualan”. Sedangkan menurut Hindle dan Thomas dalam Fandy Tjiptono (2008) Layanan purna jual adalah suatu layanan yang disediakan oleh produsen kepada konsumen setelah konsumen tersebut membeli produk dari perusahaan tersebut.

Implementasi strategi pemasaran produk Sangdo Agriculture di PT.Altrak 1978 masih belum maksimal.

1. Posisi daya saing produk Sangdo Agriculture PT.Altrak 1978 yang masih rendah tidak akan meningkat apabila tidak mampu memberikan produk dengan inovasi dan pelayanan purna jual yang baik.

2. Produk Sangdo Agriculture PT.Altrak 1978 masih memerlukan perbaikan strategi pemasaran.

\section{METODOLOGI PENELITIAN Metode Yang Digunakan}

Dalam penelitian ini metode penelitian yang digunakan adalah penelitian kualitatif. Peneliti memilih kualitatif di karenakan metode ini memiliki penekanan pada lingkungan yang alamiah, induksi, fleksibel pengalaman secara langsung, kedalaman, dan partisipasi aktif dari partisipan dan penafsiran.

\section{Tempat dan Waktu Penelitian}

1. Tempat Penelitian

Penelitian ini dilakukan di PT.Altrak 1978 Jl. RSC. Veteran No. 4 Bintaro Rempoa Jakarta Selatan, telpon 021-7361978 pada Department Auxiliary Product yang memasarkan produk-produk perusahaan termasuk produk Sangdo Agriculture.

2. Waktu Penelitian

Waktu penelitian ini dilakukan kurang lebih selama tiga bulan yaitu dimulai dari bulan Maret 2018 sampai dengan Mei 2018, penelitian ini di lakukan secara bertahap hingga tercukupi kebutuhan data dan informasi penelitian ini.

\section{Rancangan Analisis Data}

\section{Matrik SWOT}

Menurut Umar analasis SWOT yaitu matriks Threat - Opportunities - Weaknesses-Strengths(SWOT)yang merupakan matching tool yang penting untuk membantu para manajer mengembangkan empat tipe strategi Perumusan strategi tersebut menggunakan matriks SWOT (Strengths, Weaknesses, Opportunities, dan Threats). Matriks SWOT yang dibuat akan menggambarkan bagaimana peluang dan ancaman eksternal digabungkan dengan kekuatan dan kelemahan. Sehingga menghasilkan suatu rumusan strategi pengembangan peningkatan daya saing PT.Altrak 1978.

Rumusan strategi ini akan menghasilkan empat alternatif strategi, yaitu strategi kekuatan dan peluang (strategi S-O), kelemahan dan peluang (strategi W-O), kekuatan dan ancaman (strategi S-T), serta strategi kelemahan dan ancaman (strategi W-T). Matriks SWOT digunakan untuk menetapkan atau menentukan strategi peningkatan daya saing di PT.Altrak 1978 berdasarkan kekuatan, kelemahan, peluang dan ancaman. Sebelum perumusan strategi peningkatan daya saing produk Sangdo Agriculture di PT.Altrak 1978 dimasukan dalam analisis SWOT, terlebih dahulu dimasukkan ke dalam diagram SWOT. Tujuannya adalah untuk mengetahui posisi perusahaan untuk kondisi sekarang berada pada kuadran sebelah mana sehingga strategi yang dipilih merupakan strategi yang paling tepat karena sesuai dengan kondisi internal dan eksternal yang dimiliki perusahaan saat ini.

Analisis SWOT digambarkan ke dalam matriks SWOT dengan kemungkinan empat alternatif strategi yaitu strategi kekuatan dan peluang(strategi S-O), kelemahan dan peluang (strategi W-O), kekuatan dan ancaman(strategi S-T), serta kelemahan dan ancaman (strategi W-T). Adapun model dari matriks SWOT yang digunakan adalah seperti pada Tabel di bawah ini.

Keempat strategi tersebut adalah:

a. Strategi strengths opportunities (SO)

Strategi ini menggunakan kekuatan internal perusahaan untuk meraih peluang-peluang yang ada diluar perusahaan.

b. Strategi strength threats (ST). Melalui strategi ini perusahaan berusaha untuk menghindari atau mengurangi dampak dari ancaman-ancaman eksternal.

c. Strategi weaknesess opportunities (WO). Strategi ini bertujuan untuk memperkecil kelemahan-kelemahan internal perusahan dengan meman- 
faatkan peluang-peluang eksternal.

d. Strategi weaknesess threats (WT). Strategi ini merupakan taktik untuk bertahan dengan cara mengurangi kelemahan intenal serta menghindari ancaman.

Keempat strategi tersebut dikembangkan melalui key success factor pada sel yang berlabelkan $\mathrm{S}, \mathrm{W}, \mathrm{O}$, dan T. Berikut delapan tahap penentuan startegi melalui matriks SWOT :

a. Buat daftar peluang eksternal perusahaan

b. Buat daftar ancaman eksternal perusahaan

c. Buat kekuatan kunci internal perusahaan

d. Buat kelemahan kunci perusahaan

e. Cocokan kekuatan-kekuatan internal perusahaan dan peluang-peluang eksternal dan catat hasilnya dalam sel strategi SO

f. Cocokan kelemahan-kelemahan internal perusahaan dan peluang-peluang eksternal dan catat hasilnya dalam sel strategi WO

g. Cocokan kekuatan-kekuatan internal dan ancaman-ancaman

h. eksternal dan catat hasilnya dalam strategi ST

i. Cocokan kelemahan-kelemahan internal dan ancaman-ancaman

j. eksternal dan catat hasilnya dalam sel strategi WT.

2. Matriks Strategic Position and Action Evaluation (SPACE)

Menurut David, Fred, R (2009)

Dalam Umar (2001:230) Langkah-langkah menyusun Matrix SPACE sebagai berikut:

a. Pilih sejumlah variabel untuk mengukur financial strength (FS), competitive advantage (CA), environmental stability (ES), dan industry strength (IS).

b. Beri tanda dengan angka berurutan dari +1 (paling buruk) sampai dengan +6 (paling baik) untuk variabelvariabel dari dimensi FS dan IS. Beri tanda angka dengan berurutan dari -1 (paling baik) sampai -6 (paling buruk) bagi variabel -variabel dimensi ES dan CA.

c. Hitung nilai rata-rata variabel tiap dimensi FS, CA, IS dan ES. Kemudian petakan nilai rata -rata FS, CA, IS dan ES pada sumbu di SPACE Matrix.

d. Jumlahkan kedua nilai pada dimensi $\mathrm{X}$ (CA dan IS) dan petakan hasilnya pada sumbu X. Juga jumlahkan kedua nilai pada dimensi Y (FS dan ES) dan petakan hasilnya pada sumbu Y. Selanjutnya, petakan perpotongan kedua titik X dan Y tersebut.

e. Gambarkan arah vektor dari koordinat o.o melalui titik perpotongan yang baru. Tanda panah ini memperlihatkan tipe strategi yang disarankan untuk perusahaan, apakah strategi aggressive, competitive, defensive, atau conservative. Kekuatan Finansial Mencakup ukuran-ukuran yang menunjukkan kekuatan finansial yang dimiliki perusahaan, seperti : profitabilitas, likuiditas, aliran uang kas, skala ekonomi, lebih jelasnya dapat I lihat pada tabel dibawah ini.

\section{HASIL PENELITIAN \\ DAN PEMBAHASAN}

Strategi pemasaran yang saat ini di jalankan oleh PT. Altrak 1978

1. Kondisi PT.Altrak 1978 berdasarkan indikator yang menunjukkan kekuatan (Strength)

a. Dealer Network, mencakup lebih dari 40 cabang perusahaan yang tersebar di seluruh wilayah Indonesia, jaringan marketing dan purna jual perusahaan yang luas merupakan salah satu kekuatan bagi PT.Altrak 1978 sebagai dealer dari produk-produk ternama, pada bulan Juni 2018 genap 40 tahun PT.Altrak beroperasi di Indonesia telah di resmikan kantor cabang ke 40 di kota Makasar oleh CEO PT.Altrak 1978, cabang ini di lengkapi dengan satu buah depo di kota Kendari yang akan mencover penjualan produk dan pelayanan purna jual bagi customer di wilayah kendari dan sekitarnya, selanjutnya perusahaan terus mengembangkan dan merencanakan pendirian kantor cabang di wilayah Indonesia timur seperti di Sorong Papua, Kupang Nusa Tenggara Timur dan Palu, untuk lebih jelasnya mengenai jaringan kantor cabang perusahaan

b. Excusive dealership dari principal, PT.Altrak 1978 sebagai distributor dengan kekuatan jaringan pelayanan lebih dari 40 kantor cabang yang tersebar di seluruh wilayah Indonesia dalam memasarkan produk-nya hanya menjadi agen tunggal atau distributor tunggal di Indonesia dari pro- 
duk-produk tersebut, hal ini artinya produk tersebut hanya dapat di beli di kantor cabang PT.Altrak 1978 yang ada dan tidak dapat dibeli di perusahaan lain, dengan agreement seperti ini memungkinkan perusahaan mendapatkan supporting dan proteksi dari principal-nya dan memudahkan principal untuk memonitor penjualan produknya melalui jalur distribusi yang di jalankan oleh PT.Altrak 1978. Disamping itu sistem penjualan dan distribusi ini dapat meminimalisir masuknya produk-produk tiruan di wilayah pemasaran, keuntungan lainnya dengan menjalankan system distribusi ini adalah pengorbanan atau cost yang dikeluarkan oleh dealer untuk kegiatan marketing baik berupa promosi, iklan, customer gathering, dan aktifitas pemasaran lainnya hasilnya akan kembali dan dinikmati oleh perusahaan bukan oleh perusahaan lain, hal ini berbeda dengan sistem distribusi produk yang menggunakan system multi channel, promosi yang dilakukan oleh distributor bisa saja hasilnya di nikmati oleh distributor lain.

c. Jumlah CSO sebanyak 60 personel yang tersebar di setiap kantor cabang merupakan salah satu kekuatan PT.Altrak 1978 selaku distributor, Customer Service Officer adalah Sales Force atau tenaga penjual yang menerima insentif atas setiap penjualan produk di PT.Altrak 1978, coverage area setiap CSO di atur oleh seorang Sales Supervisor yang melapor ke branch manager cabang, tugas CSO adalah menawarkan dan menjual produk-produk perusahaan sesuai dengan areanya masing-masing, dengan sebaran kantor cabang yang hampir berada di setiap kota besar di setiap provinsi hal ini merupakan salah satu keunggulan PT.Altrak1978 dibanding dengan kompetitornya yang menawarkan produk sejenis Sangdo Agriculture, setiap CSO mempunyai jadwal kunjungan wajib kepada customer yang telah membeli produk dari PT.Altrak 1978, dengan demikian CSO juga mempunyai kesempatan untuk melakukan cross selling atau up-selling yaitu menawarkan produk lainnya pada customer yang sama atau dengan menawarkan produk yang sama dengan kualitas atau fitur yang lebih baik, apabila di terapkan kedua teknik tersebut akan sama-sama membantu meningkatkan penjualan.

d. Fasilitas workshop, tehnisi dan tools yang tersedia di setiap kantor cabang, sesuai dengan filsafat perusahaan; As a Sole Agent and Distributor of high class products, ALTRAK 1978 is committed to put the company's philosophy, "Your Total Partner", into reality. Every sale of the product is always accompanied by adequate product supports, which include excellent parts availability, factory trained technicians, as well as relevant training. Bahwa perusahaan berkomitment untuk menyediakan dan mendukung setiap produk yang di jual perusahaan dengan menyiapkan tehnisi atau mekanik yang terlatih yang di lengkapi dengan perlengkapan dan bengkel yang memadai di kantor cabang perusahaan, hal ini adalah salah satu kekuatan PT,Altrak 1978 yang mana dengan menginvestasikan dana pada fasilitas-fasilitas tersebut akan menjadikan PT.Altrak 1978 sebagai distributor yang terkemuka di bidangnya.

e. Ketersediaan Spare Parts di setiap cabang perusahaan, menurut Philip Kotler salah satu indikator penyediaan Pelayanan Purna Jual adalah ketersediaan suku cadang.

Dalam pelaksanaan layanan purna jual, penyediaan suku cadang merupakan hal yang sangat penting, sebab tanpa adanya suku cadang produk yang sudah rusak komponennya tidak dapat berfungsi dengan baik, bahkan produk tersebut tidak dapat dipakai lagi. Thomas A. Gannon (1987: 88) dalam Philip Kotler (2002: 509) mengatakan ;

A service parts is that component or subassembly that may be needed at some time to keep the appliance or device operable for the user. The component or assembly will be required to satisfy the original warranty repair the appliance or device beyond the basic warranty period, and be available at all the times to insure and protect the good will of purchases to the and that be will maintains his brand loyalty.

Jadi penyediaan accessories 
merupakan salah satu faktor yang memegang peranan penting dalam usaha untuk memuaskan konsumen, yang pada akhirnya akan mempertahankan loyalitas pelanggan yang sudah dimiliki. PT.Altrak 1978 memiliki sistem penyediaan suku cadang yang terintegrasi ke seluruh cabang perusahaan dan sehingga setiap kebutuhan suku cadang atas produk-produk yang di jual dapat di ketahui secara online dan real time, hal ini merupakan salah satu kekuatan distributor yang mana kecepatan pengadaan suku cadang adalah andalan dari setiap distributor.

2. Kondisi PT.Altrak 1978 berdasarkan indikator yang menunjukkan kelemahan (Weakness)

a. Terlalu banyak produk dalam perusahaan sehingga CSO atau tenaga penjual kurang fokus. Ada sekitar 23 produk perusahaan dari berbagai merek dan market segment yang harus di pasarkan oleh CSO di mana satu produk bisa terdiri dari bermacammacam model dan kapasitas, sementara satu orang CSO di main branch bisa menghandle lebih dari seratus customer tergantung size cabang, dengan kondisi seperti ini sebagian besar tenaga penjual akan memprioritaskan fleet customernya atau produk-produk yang dapat men-generate revenue dengan cepat sehingga CSO dapat mencapai target penjualan.

b. Produk kurang mengikuti perkembangan dan kebutuhan pengguna. Desain peralatan mekanisasi pertanian seharusnya mengikuti kebutuhan di lapangan, customer sebagai pengguna selalu akan memilih produk yang sesuai dengan kebutuhannya, perkembangan peralatan mekanisasi pertanian sangat dinamis produk yang ditawarkan Sangdo Agriculture masih tertinggal dari produk-produk buatan competitor yang sangat inovatif, semakin hari umur product life cycle mekanisasi pertanian semakin pendek, kompetitor begitu cepat mengeluarkan model-model terbaru yang selalu di minati oleh konsumen, sementara produk yang ditawarkan Sangdo masih memerlukan banyak modifikasi di lapangan untuk dapat bekerja dengan baik, sementara produk competitor dapat langsung di gunakan tanpa memerlukan banyak modifikasi dalam pemakaiannya, hal ini sangat disenangi oleh customer perkebunan sawit terutama produk buatan Italy dan Malaysia yang di anggap sudah sesuai dengan keinginan pengguna.

c. Kemampuan dan penguasaan tehnisi terhadap produk yang rendah, tehnisi merupakan ujung tombak perusahaan dalam menyelesaikan setiap permasalahan yang bersifat tehnikal, dari keluhan customer terhadap hal ini di lapangan terlihat kemampuan tehnisi dalam menangani permasalahan produk ini masih rendah, mulai dari lamanya penyelesaian perbaikan sampai tidak adanya informasi dan progress atas perbaikan unit yang rusak menjadi keluhan customer, hal-hal seperti ini menjadi peluang bagi competitor untuk terus menekan penetrasi yang di lakukan Altrak 1978 terhadap produk ini,

d. Harga jual yang kurang kompetitif, ditengah persaingan antar produk yang sangat ketat harga jual produk Sangdo terbilang tinggi di banding dengan competitor yang sudah menguasai pasar, hal ini merupakan salah satu kelemahan yang dapat menghambat pertumbuhan dan penjualan produk ini, harga merupakan salah satu faktor penentu bagi customer untuk memutuskan membeli atau tidaknya suatu produk disamping faktor lainnya, dengan harga jual yang lebih tinggi dari kompetitor yang ada maka akan membuat pemasaran produk sangdo semakin tersendat.

e. Kualitas produk yang kurang memadai, menurut Etta Mamang Sangadji dalam perilaku konsumen bahwa konsumen memiliki harapan mengenai bagaimana seharusnya produk tersebut berfungsi (performance expectation). Harapan tersebut adalah standar kualitas yang akan di bandingkan dengan fungsi atau kualitas produk sesungguhnya dirasakan konsumen. Fungsi produk sesungguhnya yang dirasakan konsumen (actual performance) sebenarnya merupakan persepsi konsumen terhadap kualitas produk tersebut.

Dari informasi customer, tenaga penjual dan laporan mekanik atas tingginya frekwensi permintaan perbaikan produk ini terutama selama 
masa garansi, menyiratkan bahwa kualitas produk ini perlu mendapatkan perhatian dari produsen, menurut service manager yang menangani produk ini, kurang lebih dua puluh lima persen dari total produk yang terjual mengajukan claim garansi, dengan claim rate yang demikian tinggi mengindiksikan kualitas produk kurang baik sehingga akan sulit bagi pemasar atau CSO untuk meningkatkan volume penjualan.

3. Kondisi PT.Altrak 1978 berdasarkan indikator yang menunjukkan Peluang (Opportunity)

a. Kebutuhan peralatan mekanisasi pertanian jenis grabber yang semakin meningkat di perusahaan- perusahaan perkebunan sawit. Salah satu jalan keluar untuk meningkatkan produktivitas adalah mekanisasi. Di tengah kesulitan mendapatkan lahan dan minimnya sumber daya manusia berkualitas, mekanisasi sebaiknya dilakukan secara maksimal. Untuk saat ini implementasinya masih terbatas dan baru dijalankan perusahaan sawit berskala besar, pentingnya penerapan mekanisasi di perkebunan kelapa sawit dalam upaya meningkatkan produktivitas lahan dan tenaga kerja. Mekanisasi adalah kegiatan menggunakan alat bantuan mekanik menggantikan pekerjaan yang biasa dilakukan tenaga manusia maupun hewan dalam mengelola lahan. Jenis alat mekanik yang digunakan pada perkebunn kelapa sawit antara lain traktor, alat panen mekanis, truk, dan lain-lain. Kegiatan mekanisasi yang berbasiskan kepada mesin dan teknologi saat ini masih terfokus kepada kegiatan on farm. Di tahapan aktivitas kebun, mekanisasi dijalankan pada kegiatan pembukaan lahan, pemupukan, pemanenan, dan pengangkutan bibit serta buah sawit.

b. Biayatenagakerja disektor perkebunan yang semakin meningkat dari tahun ketahun. Permasalahan umum perusahaan sawit di Kalimantan dan Sumatera adalah kurangnya pasokan tenaga kerja di bidang perkebunan kelapa sawit. Tenaga kerja yang ada tidak banyak yang berminat untuk bekerja di perkebunan sawit para tenaga kerja lebih senang bekerja di sektor lain, misalnya bekerja di pabrik di perkotaan. Walaupun perusahaan sawit dalam negeri selalu berusaha memberi upah di atas upah minimum provinsi minat masyarakat untuk bekerja di sektor ini tetap rendah. Kebun sawit biasanya dibuka di luar Jawa, misalnya Sumatera dan Kalimantan, sehingga tidak banyak tersedia angkatan kerja berusia produktif seperti di Jawa, kekurangan tenaga kerja itu terjadi karena ekspansi perusahaan sawit yang sangat agresif.

Rendahnya animo masyarakat untuk bekerja di sektor perkebun sawit ini memaksa para pengusaha sawit untuk memikirkan cara lain termasuk mengimplementasikan mekanisasi pertanian untuk menutupi kekurangan buruh tani tersebut, hal ini merupakan peluang bagi PT.Altrak 1978 untuk turut serta berkontribusi dalam menyediakan peralatan mekanisasi pertanian bagi perusahaan-perusahaan sawit.

c. Belum banyak perusahaan besar yang menggarap bidang ini dengan serius. Peralatan mekanisasi pertanian untuk kebutuhan perkebunan sawit biasnya di aplikasikan pada traktor pertanian walaupun ada beberapa yang diaplikasikan pada peralatan lainnya seperti truck ataupun crawler carrier namun kebanyakan digunakan pada traktor pertanian, PT.Altrak 1978 sebagai distributor traktor pertanian merek New Holland dengan pangsa pasar untuk jenis traktor asal Eropa dan Amerika di atas 50\% mempunyai peluang besar dalam mengembangkan produk Sangdo Agriculture, yang mana dealer-delaer traktor pertanian lainnya masih belum banyak yang dapat mensupply peralatan mekanisasi sejenis grabber ini, kebanyakan dari mereka masih membeli grabber ke supplier lain.

d. Tehnologi yang masih dapat terus di kembangkan sehingga membutuhan banyak inovasi-inovasi baru. Tehnologi mekanisasi pertanian kelapa sawit sangat dinamis dan terus berkembang dari tahun ke tahun, di butuhkan banyak inovasi di bidang ini untuk memenuhi kebutuhn pertanian kelapa sawit di Indonesia, dari data kementrian Perindusrian Indonesia, Indonesia merupakan penghasil kelapa sawit terbesar di dunia, dengan 
kondisi market yang demikian luas perusahaan dan principalnya mempunyai peluang yang sangat besar untuk mengembangkan tehnologi dan membuat inovasi-inovasi di bidang mekanisasi pertanian sesuai dengan kebutuhan dan potensi pasar yang ada.

e. Kepuasan customer yang telah menggunakan produk jenis lainnya dari perusahaan dapat di jadikan dasar pengembangan pemasaran produk ini. Posisi PT.Alrak 1978 sebagai dealer dari peralatan berat perlatan konstruksi, peralatan pertanian dan pembangkit listrik terkenal mempunyai basis customer (customer database) yang loyal atas penggunaan dari produk-produk tersebut, menurut Tjiptono, (2000:105), terciptanya kepuasan dapat memberikan beberapa manfaat diantaranya, hubungan antara perusahaan dan pelanggan dapat menjadi harmonis sehingga dapat menjadi dasar yang baik bagi pembelian ulang dan terciptanya kesetiaan terhadap merek serta membuat suatu rekomendasi dari mulut ke mulut yang menguntungkan bagi perusahaan, hal tersebut di atas dapat di jadikan sebagai dasar pengembangan produk ini.

4. Kondisi PT.Altrak 1978 berdasarkan indikator yang menunjukkan Ancaman (Threat)

a. Produk kompetitor yang telah menguasai pasar lebih dulu dan sudah mendapat kepercayaan konsumen. Kompetitor utama dari produk ini berasal dari Negara Malaysia dan Italia mempunyai populasi unit yang sudah cukup banyak tersebar di area Sumatera dan Kalimantan, penguasaan pangsa pasar oleh kompetitor ini tidak terlepas dari penetrasi yang telah di lakukan kompetitor jauh-jauh hari sebelum banyak pemain dan produsen lain yang masuk pada pasar ini.

b. Inovasi produk yang dilakukan kompetitor sangat agresif dan mendapat perhatian dari konsumen. Dalam melakukan pemasaran produknya, kompetitor senantiasa melakukan inovasi produk dengan cara melibatkan langsung customer sebagai pengguna akhir, sehingga hasil dari inovasinya akan mendekati ekpektasi customer, keterlibatan customer ini juga sekali- gus sebagai sebagai sarana promosi dan menambah minat dan konsistensi customer terhadap produk yang telah di belinya, hal ini merupakan ancaman bagi produk Sangdo di wilayah pemasaran yang sama.

c. Harga jual pesaing yang sangat kompetitif merupakan ancaman serius bagi perusahaan. Harga merupakah salah satu faktor yang dapat menarik customer untuk membeli disamping promosi dan kualitas produk, strategi penetapan harga yang telah di tetapkan kompetitor telah mendapatkan response positive dari customer terbukti dengan peningkatan jumlah penjualan dan populasi unit kompetitor pasar. Harga jual yang murah dari kompetitor merupakan ancaman serius bagi PT.Altrak 1978 dalam mengembangkan pemasaran produk Sangdo Agriculture.

d. Komentar dan pengalaman yang buruk dari konsumen bisa mempengaruhi calon pembeli yang lain. Menurut Sangadji dalam perilaku konsumen menyatakan pentingnya kredibilitas sumber informal, informasi yang di peroleh dari sumber informal seperti teman, keluarga, rekan kerja tetangga, dan sebagainya yang memiliki kedekatan hubungan akan lebih di percaya konsumen sebagai penerima informasi, oleh karena itu komuniksi dari mulut kemulut berdampak nyata, dan luar biasa. Hasil survei menyatakan bahwa dampak konsumen yang tidak puas dengan pelayanan penjual bisa lebih dari 40\%, menyebar melalui kominikasi dari mulut ke mulut, Pengalaman menkonsumsi suatu produk, baik konsumen puas maupun tidak puas, akan menjadi pengalaman konsumen di kemudian hari. Pengalaman buruk beberapa konsumen yang membeli produk Sangdo Agriculture dapat mempengaruhi calon konsumen lainnya.

e. Munculnya konsep-konsep peralatan mekanisasi baru dapat mengancam eksistensi dari produk jenis ini. Perkembangan tehnologi mekanisasi yang dinamis dan terus berkembang seiring dengan pemintaan pasar. Produkproduk baru terus bermunculan dan memancing minat konsumen. Konsumen yang selama ini menggunakan produk jenis ini dapat saja berubah 
pikiran dengan uji coba-uji coba yang di lakukan oleh pemasar produk baru tersebut.

Ancaman produk pengganti, dimana ancaman yang harus di antisipasi oleh setiap perusahaan. Adanya produk pengganti, sering dapat mengurangi keinginan konsumen untuk membeli produk exsisting dan berusaha membeli produk pengganti tersebut, apalagi produk pengganti tersebut di sediakan dengan manfaat yang lebih minimal sama atau lebih baik, harga lebih terjangkau, produk ada dan tersedia serta pelayanan yang lebih baik.

\section{SIMPULAN}

\section{Kesimpulan}

1. Strategi pemasaran yang di jalankan PT.Altrak978 saatiniadalahmemanfaatkan dealer network yang mencakup lebih dari 40 cabang perusahaan yang tersebar di seluruh wilayah Indonesia. Menggunakan kekuatan exclusive dealership dari principal sebagai proteksi atas produk yang di pasarkan. Menggunakan tenaga pemasaran atau CSO yang berjumlah sebanyak 60 orang yang tersebar di setiap cabang. Menyediakan fasilitas workshop, tehnisi dan tools yang tersedia di setiap cabang. Serta menyediakan spare parts di setiap cabang perusahaan.

2. Posisi daya saing PT.Altrak 1978 saat ini adalah berada pada kuadran 1, yaitu dimana perusahaan berada pada kondisi kuat dan mempunyai peluang yang sangat besar untuk maju pesat, pada kuadran ini organisasi perusahaan berada pada kondisi prima sehingga sangat memungkinkan untuk terus melakukan pengembangan, meningkatkan pertumbuhan untuk meraih kemajuan secara maksimal.

3. Strategi pengembangan Product Sangdo Agriculture yang di rekomendasikan adalah pertumbuhan agresif (growth oriented strategy) dengan empat alternatiF strategi yaitu :

a. Strategi (S-O), meningkatkan jumlah kunjungan CSO fokus ke perkebunan kelapa sawit untuk memperkenalkan keunggulan produk Sangdo secara masif. Meningkatkan frekuensi promosi produk melalui, iklan, customer gathering dan produk seminar. Mengembangkan pemasaran produk Sangdo kepada existing customer yang sudah menggunakan produk lainnya dari perusahaan. Serta bekerja sama dengan distributor traktor pertanian lain untuk menggunakan produk Sangdo pada Traktor yang dipasarkannya.

b. Strategi (W-O), mendedikasikan CSO khusus untuk menangani produk Sangdo pada cabang-cabang yang berpotensi. Meningkatkan kualitas produk melalui research pengembangan produk dari principal langsung ke end user. Melakukan research pasar untuk menetapkan strategi harga. Melakukan efisiensi biaya untuk menekan harga jual, serta melakukan pengembangan dan pemasaran produk dengan desain applikasi yang berbeda dengan kompetitor.

c. Strategi (S-T), melakukan pemasaran produk Sangdo dengan membuat paket produk kombinasi dengan traktor pertanian yang tidak dimiliki oleh kompetitor. Fokus dalam produk inovasi dengan melibatkan customer sebagai pengguna akhir serta menjalin komunikasi yang efektif dengan perusahaan-perusahaan perkebunan kelapa sawit.

d. Strategi (W-T), memanfaatkan jaringan pelayanan purna jual perusahaan yang sudah mapan untuk memasarkan produk ini, fokus pada wilayah yang belum di garap kompetitor. Meningkatkan kualitas dan kompetensi tehnisi melalui pemberian technical training yang berkesinambungan. Meningkatkan coverage kunjungan CSO dan membangun komunikasi ke pelanggan-pelanggan baru.

\section{Saran}

a. PengembanganpemasaranprodukSsangdo Agriculture sebaiknya dilakukan dengan cara terintegrasi dengan memaksimalkan kekuatan dan memanfaatkan peluang serta meningkatkan dan melakukan improvement pada kelemahan, menghindari dan mengantisipasi ancaman.

b. Masih ada beberapa kekurangan yang harus di perbaiki atau ditingkatkan oleh pihak PT.Altrak 1978, sehingga dapat dijadikan masukan agar kedepannya dapat memberikan kontribusi yang positif bagi kemajuan perusahaan antara lain kualitas produk yang memerlukan improvement yang melibatkan principal perusahaan dan pelanggan. Perusahaan juga perlu untuk 
lebih fokus dalam produk inovasi dengan melibatkan customer.

c. Perusahaan juga perlu melakukan antisipasi untuk mengatasi kelemahan dengan cara meningkatkan kualitas dan kompetensi tehnisi melalui pemberian technical training yang berkesinambungan, meningkatkan coverage area kunjungan CSO dan membangun komunikasi ke pelanggan-pelanggan baru. Selain itu perusahaan disarankan untuk melakukan efisiensi biaya serta melaksanakan research pasar untuk menetapkan strategi harga yang lebih kompetitive.

\section{DAFTAR PUSTAKA}

Abdullah, Thamrin \& Tantri, Francis. 2012. Manajemen Pemasaran. Penerbit PT. Raja Grafindo Persada, Jakarta.

Arikunto, Suharsimi. 2006. Metodologi Penelitian. Yogyakarta. Bina Aksara.

Atmosudirjo, Prajudi. 2012. Dasar dasar Adminisrasi Manajemen dan Manajemen Kantor. Gunug Agung, Jakarta.

Basu Swasta, Irawan. 2003. Manajemen Pemasaran Modern. Edisi Kedua, Cetakan Kesebelas, Yogyakarta. Liberty Offset.

Bungin, Burhan. 2004. Metodologi Penelitian Kuantitatif. Edisi Pertama. Penerbit Prenada Media Group. Surabaya.

Churchill, Gilbert. 2001. Dasar-Dasar Riset Pemasaran. Edisi Keempat jilid pertama. Penerbit Erlangga. Jakarta.

David, Fred R. 2006. Manajemen Strategi. Edisi keempat. Penerbit Erlangga. Jakarta.

Etta Mamang Sangadji. 2013. Prilaku Konsumen. Penerbit Andi Offset.

Freddy Rangkuti.2011. Riset Pemasaran. Cetakan ke 10. Jakarta : Percetakan PT. Gramedia.

Hisrich, Robert D, dan Peters, Michael,P.2003. Enterpreneurship, Kewirausahaan. Salemba Empat. Jakarta.

Idrus, Muhamad. 2009. Metode Penelitian Ilmu Sosial. Penerbit Gelora Aksara Pratama.

Indriyo Gitosudarmo. 2001. Prinsip Dasar Manajemen. Edisi ketiga, BPFE. Jogjakarta.

Kotler, Philip, \& Amstrong. Gary. 2008. Prinsip-Prinsip Pemasaran. Edisi Kedua belas jilid satu. Penerbit Erlangga, Jakarta.

Kotler, Philip, \& Keller, Kevin Lane. 2009. Manajemen Pemasaran. Edisi Tiga belas jilid satu. Penerbit Erlangga. Jakarta.

Kotler, Philip, \& A.B Susanto.2000. Manajemen Pemasaran Indonesia. Alih Bahasa: Ancela
Anitawatai \& Hermawan. edisi Pertama, Penerbit Salemba Empat, Jakarta.

Kotler, Philip. 2002. Strategi Pemasaran Untuk Organisasi Nirlaba. Edisi Ketiga. Universitas Gajah Mada,.

Kotler, Philip. 2002. Manajemen Pemasaran. Alih Bahasa: Hendra Teguh dkk. Edisi 1. Jakarta: PT Perhalindo.

Kotler, Philip, \& Keller, Kevin Lane. 2013. Manajemen Pemasaran. Edisi Tiga belas jilid satu, Penerbit Erlangga. Jakarta.

Kotler, Phillip, \& Amstrong, Gary. 2002. DasarDasar Pemasaran. Jilid 1, Alih Bahasa Alexander Sindoro dan Benyamin Molan. Jakarta. Penerbit Prenhalindo.

Kountour, Ronny. 2008. Riset Pemasaran, Seri Manajemen Pemasaran”, No.20. PT. Mitra Kerjaya, Jakarta.

Kuncoro, Mudrajad. 2009. Metode Riset untuk Bisnis dan Ekonomi. Penerbit Erlangga. Jakarta.

Leon G. Schiffman, Leslie Lazar Kanuk. 2007. Perilaku Konsumen, Edisi Bahasa Indonesia, Edisi Ketujuh. Penerbit PT. Indeks Kelompok Gramedia. Jakarta.

Malhotra, Naresh. 2006. Riset Pe.masaran Pendekatan Terapan. Edisi Keempat Jilid Kedua. Penerbit PT Indeks Kelompok Gramedia. Jakarta.

Mariotti, Jhon. 2003. Marketing Express. Penerbit Prestasi Pustakaraya. Jakarta.

McCarty E, Jerome\& Perreault D, William. 1993. Intisari Pemasaran Sebuah Ancangan Manajerial Global. Edisi Keenam jilid satu. Penerbit Binarupa Aksara, Jakarta..

Mulyadi. 2008. Sistem Akutansi. Penerbit. Salemba empat, Jakarta.

Moleong.Lexi J. 2004. Metode Penelitian Kualitatif. Remaja Rosdakarya, Bandung.

Moleong.Lexi J. 2007. Metode Penelitian Kualitatif. PT. Remaja Rosdakarya Offset, Bandung.

Nachrowi Djalal Nachrowi, Phd. Hardius Usman, Msi. 2004. Teknik Pengambilan Keputusan. Penerbit Grasindo, Jakarta.

Nitisemito, Alex S. 2005. Prinsip Pemasaran. Edisi ketiga. Penerbit Alfabeta, Bandung.

Purwanto, Iwan. 2006. Manajemen Startegi. Penerbit CV. Yrama Widya, Bandung.

Rumidi, Sukandar. 2002. Metodologi Penelitian, Petunjuk Praktis Suntuk Peneliti Pemula. Penerbit Gadjah Mada University Press, Yogyakarta.

Saladin, Djaslim. 2003. Intisari Pemasaran \& Unsur-unsur Pemasaran. Penerbit CV. Linda Karya, Bandung.

Shimp, Terence A. 2000. Periklanan Promosi. Penerbit Erlangga. Jakarta. 
Soemarso. 2007. Akuntansi Suatu Pengantar. PT.Citra Aditya Bakti, Bandung.

Stanton, William J. 2002. Prinsip Pemasaran. Edisi Kesembilan, Cetakan Ketiga. PT. Bumi Askara, Jakarta.

Sugiyono. 2003. Metode Penelitian Manajemen. Alfabeta.

Sugiyono. 2014. Metode Penelitian Kuantitatif Kualitatif dan $R \& D$. Alfabeta.

Sunyoto, Danang. 2013. Perilaku Konsumen (Panduan Riset sederhana untuk mengenal konsumen). PT. Buku Seru, Jakarta.

Sunyoto, Danang. 2012. Dasar dasar Manajemen Pemasaran. PT. Buku Seru, Jakarta. 